\title{
Nd:YAGレーザー照射に対する菌の熱光学的反忍特性と その臨床的意義
}

CHARACTERISTICS OF PHOTO-THERMAL REACTION IN TEETH EXPOSED TO ND:YAG LASER AND THEIR CLINICAL APPLICABILITY

長沢明範 $*$ 、浅井浩 $*$ 、加藤一一 $* *$

Akinori NAGASAWA *, Hiroshi ASAI*, Kazuichi KATO**

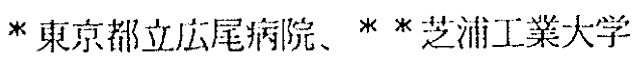

* Metropolitan Hiroo General Hospital, * * Shibaura Institute of Technology

\begin{abstract}
The author $s$ previous experiments have revealed the fact that carious dental tissues have remarkably different optical characteristics to $\mathrm{Nd}-\mathrm{YAG}$ laser light from intact dental tissnes. In this experiment Nd-YAG laser shot on the occlusal surface of extracted human teeth, and the occlusal surface temperature the reflection on the occlusal surface and the transmission from the side surface of the lased teeth were examined. The results of these data analysis proved that these photo thermal reactions of carious teeth to exposure to Nd, YAG laser remarkably different from that of intact teeth, and even the primary dental caries were able to be identified.The results of this experiment suggests that this system can newly develop a very sensitive diagnostic technique for dental caries.
\end{abstract}

萻者らはこれまでに行なった藏貿の分光分析や

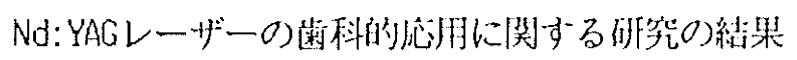
から、同レーザーに対する简の吸収、透過等の光 学特性は歯質の性状によって異なることを子知し

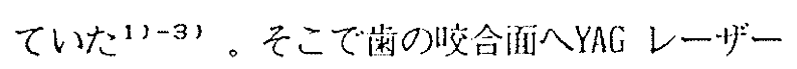

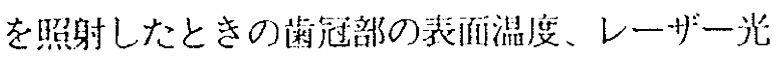
の透過ならびに反射などの们们奖動を計测し、健

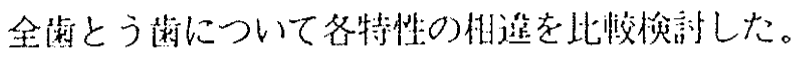
测䇥方洁

人の报去莱の咬合酒へNd:YAGレーザーを器勆し、 
咬合面の温度、咬合涌でのレーザーの反射光、蒾 冠側面へのレーザーの透過光の变動を記録垉祭し た。菌の表面温度は感光波長芰域 $7-11 \mu \mathrm{m}$ の医用 赫外放射温度訃で、透過光や仅射光の相刘強度は 可及的に光吸収特性を高好るよう表面处理を㴯し たCA型熱電刘で計测し、POC 機椎をもったレコー ダーに経時的に同時記録した。さらに、苗質のレ 一ザー光分有はCCD TVカメシで、苗面の温度分有 はリアルタイムで西像処理の可能な畐速サーモグ ラフ880型を用いて硯测した。

実験方法ならびに実倹結果

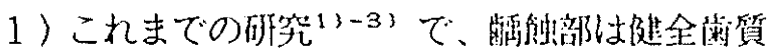
よりもNd:YAGレーザーに対し吸收性が高く、透過 性の劣ることがわかっていたが、健全菌とう菌の 咬合面へNd:YAGレーザーを照射したときの菌の州 一モグラムで以上の絬果が2次元似に碓非された (図1)。

2 ) 健全菌とう菌の咬合湎へNd:YAGレーザーを照 射したときの(1)咬合湎温度（放射温度計）(2)咬合 面での反射光強度 ( $C A$ 熱電対) と(3)菌冠側侕加

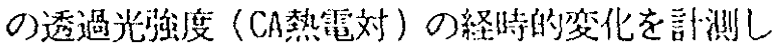
たところ、健全菌では(1)は小さいが(2)、(3)が大き く、能蝕ではこれと再者で1)、2)に示したのと相 反する予测通りの結果が得られた（図2）。この 特異的な傾问は菌科佣線写真でも検出不问能な

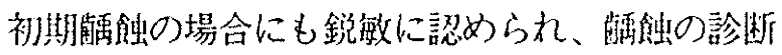
に利用磒値の高いことがわかった。

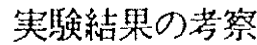

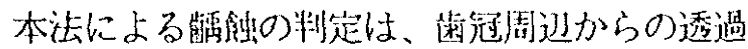
光と咬合洏温度もしくは咬合而加らの反射光の組 み合わせで可能となることがわかった。反射光強 度を単一の熱電対で测定する埸合、センサーの位 筧によって测定䛧少变わるのは、反射光強度が反 射方向依存性を持つためと考之られる。この場合 は箖分球的手法で全反射光の強度老計測する必琵 がある。一方放射温度計による表酒温度部測の場 合忟、Lambert's cosin low に基づいて测光軸の 方间に四䋆なく正しい温度が得られるので、本法

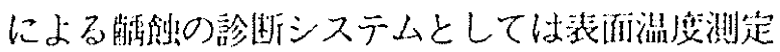
を採用するはうが好ましいと考えられる。

本システムのレーザーは过d:YAGレーザー以外に

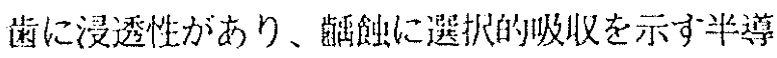

体レーザーやArレーザーも利用可能であることが 実験的に確認された。

結論

歯に照射したNd:YAGレーザーによる菌面の温度 変化と透過光強度は健全歯と蜴玲菌とで特異的な 変動を示すことがわかった。この方法は安全で高 感度の龋蝕診断法に応用できることがわかった。

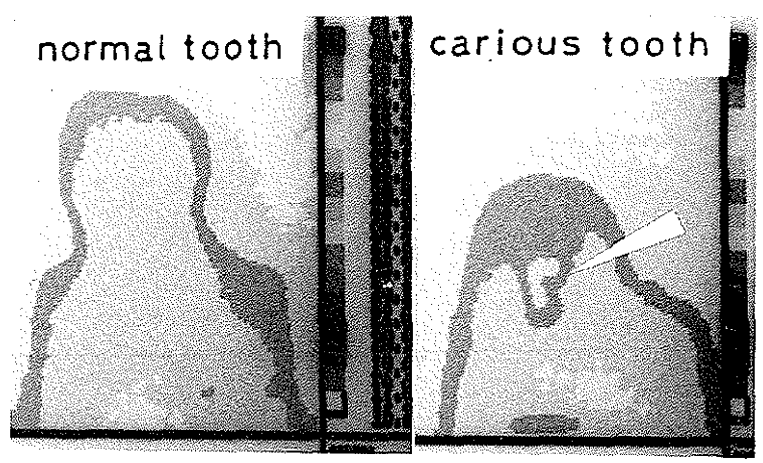

闵 1
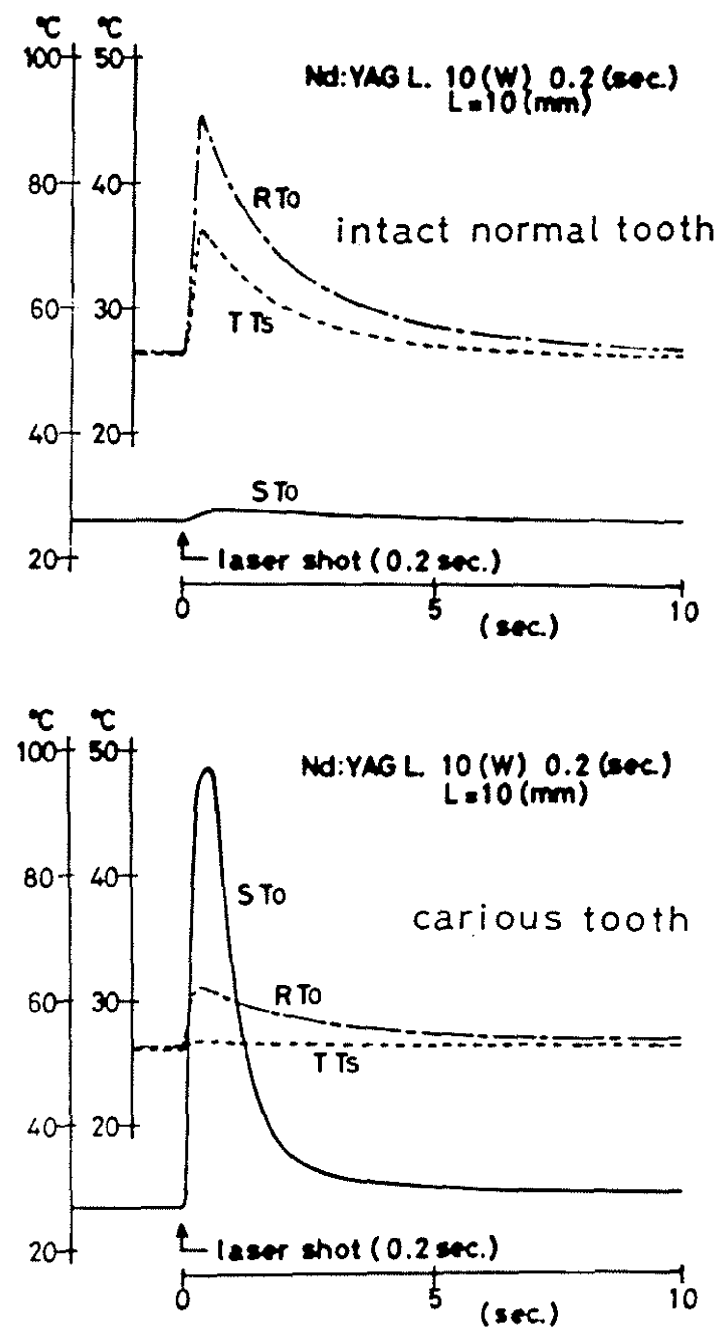

図 2 